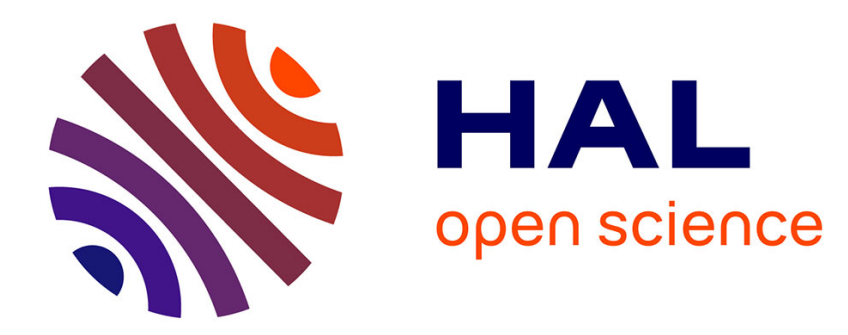

\title{
Locating Criticality in the Lexicography of Historically Marginalized Languages
}

\author{
Victoria Sear, Mark Turin
}

\section{To cite this version:}

Victoria Sear, Mark Turin. Locating Criticality in the Lexicography of Historically Marginalized Languages. History of Humanities, 2021, 6 (1), pp.237-259. 10.1086/713266 . halshs-03247198

\section{HAL Id: halshs-03247198 \\ https://shs.hal.science/halshs-03247198}

Submitted on 2 Jun 2021

HAL is a multi-disciplinary open access archive for the deposit and dissemination of scientific research documents, whether they are published or not. The documents may come from teaching and research institutions in France or abroad, or from public or private research centers.
L'archive ouverte pluridisciplinaire HAL, est destinée au dépôt et à la diffusion de documents scientifiques de niveau recherche, publiés ou non, émanant des établissements d'enseignement et de recherche français ou étrangers, des laboratoires publics ou privés. 


\title{
Locating Criticality in the Lexicography of Historically Marginalized Languages
}

\author{
Victoria Sear, University of British Columbia, Canada \\ Mark Turin, University of British Columbia, Canada
}

\begin{abstract}
A BSTRACT
In this contribution, we address a practice in which many field linguists working with endangered, Indigenous, and underresourced languages participate: the creation of a dictionary. In such lexicographical projects, there is an urgent need for language workers to become more aware of their own ideological and intellectual baggage and to explore how such projects can contribute to challenging harmful colonial research practices. Informed by long-standing traditions in lexicographical theory, this emerging self-awareness encourages researchers to reflect on the ways their dictionary work aligns with, or diverges from, established practices. We propose that by introducing a degree of criticality and self-reflexivity into lexicography, dictionary work with historically marginalized and underresourced languages can undergo an ethically productive and theoretical reorientation. We situate our contribution in the wider context of
\end{abstract}

As we finalized revisions to this contribution in July 2020, we find it not only appropriate but necessary to acknowledge that - since we submitted this article for review in 2019- the Black Lives Matter movement and other aligned grassroots antiracist social movements for equity and justice have rapidly, profoundly, and positively changed the academic and social landscape with regard to discussions of race and the perpetuation of colonial legacies and hegemonic power structures. While we do not directly speak to these movements in our contribution, we sincerely hope that our argument will make a modest contribution in identifying and overcoming the long history of discrimination and marginalization that Indigenous peoples and the languages that they speak continue to face.

We are very grateful to Daniela Merolla for assembling this issue and inviting us to be a part of this publication, and to our fellow contributors, Michiel Leezenberg, Daniela Merolla and Shamil Jeppie for making the process so stimulating and generative. We wish to acknowledge the intellectual work of Susan Arndt and appreciate having had the chance to be in conversation with her. We also thank Meryl Amos DeLorey-Tully for her recommendations of dictionary projects to reference and to Julia Schillo for her generous editorial assistance with citations and referencing. We extend our thanks to the two anonymous peer reviewers for their thoughtful feedback and constructive recommendations. Needless to say, all remaining infelicities and errors are our own.

History of Humanities, Volume 6, Number 1. https://doi.org/10.1086/713266

(C) 2021 by Society for the History of the Humanities. All rights reserved. 2379-3163/2021/0601-0013\$10.00 
critical theory, decolonial studies, and critical Indigenous studies and in the growing literature on language reclamation and Indigenous methodologies.

or researchers working with endangered, Indigenous, historically marginalized, or underresourced languages, it is likely that one of the projects they will eventually — and perhaps even inevitably — undertake is the creation of a dictionary. Lexical collection in general and dictionaries in particular offer significant value and lasting importance to language documentation, preservation, and revitalization projects, in large part because of their imagined comprehensiveness and relative accessibility. Consequently, language workers (whether members of language communities themselves or outsider researchers) can devote months, years, decades, and on occasion even entire careers to the compilation and construction of a single dictionary. In descriptive linguistics (and other related disciplines), dictionaries are infamous for being painstakingly time-intensive, complex, and involved projects to undertake. Ladislav Zgusta opens his 1971 Manual of Lexicography with the humorous if grim comment that "there can be no doubt that lexicography is a very difficult sphere of linguistic activity. Many lexicographers have given vent to their feelings in this respect. Perhaps the most colourful of these opinions based on a lexicographer's long experience is that of J. J. Scaliger (16th-17th cent.) who says in fine Latin verses that the worst criminals should neither be executed nor sentenced to forced labour, but should be condemned to compile dictionaries, because all the tortures are included in this work."

What makes lexicography such a "difficult sphere of linguistic activity" is that each and every dictionary is not simply a collection of headwords and lexical entries but rather an assemblage of historical, cultural, territorial, and often spiritual information that is meaningful for a language community at a particular time and in a particular place. True for all dictionaries, but especially for dictionaries of endangered, Indigenous, historically marginalized, or underresourced languages, these two elements are interconnected: words are meaningless without relevant contextual information, and this contextual information - what we might call "sociolexical metadata" - is arguably incomplete without the terms that are used to convey it. It is therefore no surprise that dictionary work with underresourced languages is complex and that it often takes more time and money to complete than language workers may budget at the outset.

1. Ladislav Zgusta, Manual of Lexicography, ed. Vera Cerny (Prague: Academia Publishing House of the Czechoslovak Academy of Sciences, 1971), 15. 


\section{COLONIAL LEXICOGRAPHY: DICTIONARY AS "INVENTORY" AND LEXICOGRAPHER AS "HISTORIAN"}

From the extensive and ongoing discussions in the scholarly literature, we know that dictionaries are shaped as much by the conventions of the field of lexicography as they are by the goals of their creators and the diversity of their stakeholders. This is particularly salient in the context of Indigenous and minority language projects. ${ }^{2}$ Since the inception of the field of lexicography, dictionary practitioners have debated the purpose of a dictionary, as well as the role and authority the compiler ought to assume in its construction. In 1857, Archbishop Richard C. Trench memorably informed the Philological Society that the dictionary is "the inventory of a language" and coined the often-cited axiom that the lexicographer is a "historian of it [the language], not a critic of it."

Building on this foundational moment in the field, we address the ways in which dictionary projects of, for, and in endangered, Indigenous, historically marginalized, or underresourced languages provide participants with tools that help them reevaluate their roles as historians of a language, problematize the notion that dictionaries are simply inventories of a language, and avoid becoming critics of a language. By this, we refer to instances when researchers - explicitly and inadvertently-become critics when they let their own language ideologies and expectations (informed as they are by their knowledge of majority languages) dominate those of the language community

2. Gabriele H. Cablitz, "Documenting Cultural Knowledge in Dictionaries of Endangered Languages," International Journal of Lexicography 24, no. 4 (2011): 446-62; Shobhana L. Chelliah and Willem J. de Reuse, "Lexicography in Fieldwork," in Handbook of Descriptive Linguistic Fieldwork, ed. Shobhana L. Chelliah and Willem J. de Reuse (New York: Springer, 2011), 227-49; Miriam Corris et al., "Dictionaries and Endangered Languages," in Language Endangerment and Language Maintenance: An Active Approach, ed. David Bradley and Maya Bradley (New York: Routledge, 2002), 329-47; Antonia Cristinoi and François Nemo, "Challenges in Endangered Language Lexicography," in Lexicography and Dictionaries in the Information Age: Selected Papers from the 8th ASIALEX International Conference, ed. Deny A. Kwary, Nur Wulan, and Lilla Musyahda (2013), 126-31, https:// halshs.archives-ouvertes.fr/halshs-01345620; Carrie Dyck and Ranjeet Kumar, "A Grammar-Driven Bilingual Digital Dictionary for Cayuga," Dictionaries: Journal of the Dictionary Society of North America 33 (2012): 179-204; Paul V. Kroskrity, "Designing a Dictionary for an Endangered Language Community: Lexicographical Deliberations, Language Ideological Clarifications," Language Documentation and Conservation 9 (2015): 140-57; Kevin J. Rottet, "Neology, Competing Authenticities, and the Lexicography of Regional Languages: The Case of Breton," Dictionaries of the Dictionary Society of North America 35 (2014): 208-47; Kathy R. Sikorsky, "Community-Based Lexicography," in Proceedings of the 2002 Athabaskan Language Conference, Fairbanks, Alaska, June 16-18, 2002, ed. Gary Holton (Fairbanks: Alaska Native Language Center, 2002), 173-81.

3. Richard Chenevix Trench, On Some Deficiencies in Our English Dictionaries: Being the Substance of Two Papers Read before the Philological Society Nov. 5, and Nov. 19, 1857 (London: John W. Parker \& Son, 1857), 4. 
and thereby influence understandings of what a language is or how it should be represented. To this end, we note that researchers who participate in lexicographic projects with endangered, Indigenous, historically marginalized, or underresourced languages are often faced with unique circumstances and decisions that go beyond the conventional practices of lexicography.

Coauthor Victoria Sear encountered one such unique circumstance in 2012 when she interned with a dictionary project at the Kaw Nation Language Department in Oklahoma in the United States. Since Kanza is a sleeping language with no living fluent speakers at the time, the dictionary had to be developed using accessible existing language documentation made in the period between the 1800s and the 1970s. As a way to overcome the limited number of documented words that could be included in the dictionary, the collaborating team of linguists and community members chose to deviate from conventional lexicographical practices by including snippets detailing relevant historical or cultural information in some entries. Sear learned about discussions earlier in the project regarding how many snippets were appropriate to include. While some members of the partnership felt that adding too much cultural and historical information would compromise the text's legitimacy and usability as a dictionary, others contended that if the text included extensive cultural and historical information, it would be more interesting and valuable to community members and would create an important resource about Kaw language, history, and culture. All those involved in this project were faced with difficult decisions about how to implement (or not implement) conventional lexicography practices with regard to including extralinguistic information in entries. This process entailed not only critically examining how and why they were constructing this dictionary but also asking what the dictionary itself would represent going forward and whom it would serve.

We contend that those of us engaged in this work need to critically examine the everyday implications and political impact that our lexicographic practices may havenot only within the physical or virtual pages of a dictionary but also within language communities and across increasingly globalized and digital spaces. We refer to the emergence of this process, and the examination that it entails, as "criticality in lexicography." We envision that practicing criticality in lexicography addresses the legacy of how traditional lexicography, informed by majority languages, has shaped the study of language, both structurally and discursively. Just as anthropology has been described as the "handmaiden to imperialism,"4 Siraj Ahmed has more recently argued that "new philology was

4. Marshall Sahlins, Culture and Practical Reason (1976; Chicago: University of Chicago Press, 2013), 2. 
apprenticed to colonial rule." Ahmed's compelling and intricate position revolves around identifying philology as comprising "three fundamental innovations: the invention of comparative grammar, the classification of languages into families, and the reconstruction of historically unattested protolanguages," each of which "originally served colonial rule." ${ }^{\prime \prime}$ Ahmed's contribution is to "recognize the forms of life philology itself has excluded," a method that can then be harnessed to turn "philological research against its own history" in a powerful anticolonial act. ${ }^{7}$ Only when a dictionary starts grappling with its colonial legacy can practitioners bring the discipline into a more productive and equitable space. If we adhere to the definition of internal colonialism offered by Charles Pinderhughes, namely, that it is a "system of inequality, not just an aspect of device or component of inequality," it is not outlandish to suggest that traditional lexicography can be understood as a colonized practice and that its orientations are not value neutral. Only by undertaking a critical analysis of past and present dictionary making can we address the impact that conventional lexicography practices continue to have in dictionary projects of endangered, Indigenous, historically marginalized, or underresourced languages.

The coauthors of this contribution - both of us non-Indigenous - have undertaken extensive fieldwork with speakers of Indigenous languages and have participated in increasingly collaborative dictionary projects in Asia and North America. Our previous work informs this article, in which we offer a critical analysis of the state of our field and draw on our own experiences of lexicographical partnerships. For both logistical and intellectual reasons, we primarily situate this analysis in the context of Indigenous and minority language projects in Canada and the United States. On the practical side, the momentum and innovations in current lexicographical work in Native North America is noteworthy. On the theoretical side, the languages of the continent are structurally and grammatically very distinct from European languages for and from which lexicography was originally developed. Consequently, the social and intellectual context of the creation of dictionaries for Native North American languages differs significantly from those of majority world languages, languages that — we might note- are widely understood by Indigenous communities to have colonized them

5. Siraj Ahmed, Archaeology of Babel: The Colonial Foundation of the Humanities (Stanford, CA: Stanford University Press, 2017), 38.

6. Ibid., 51.

7. Ibid., 153.

8. Charles Pinderhughes, "Toward a New Theory of Internal Colonialism," Socialism and Democracy 25, no. 1 (2011): 236. 
through education and media and whose hegemonic exclusivity continues to threaten their resurgence. ${ }^{9}$

In his contribution to this issue, Michiel Leezenberg makes the point that in the past, noteworthy scholars have been "accused of overstating the pervasiveness of hegemony of Western influence and of downplaying local agency" in the Islamic world. ${ }^{10}$ Consonant with this observation, we do not accuse any practitioners of lexicography - past or present - of overstating the pervasiveness or hegemony of Western influence in lexicography. In fact, we propose the opposite. In our discussion - and at the risk of overstating the pervasiveness of Western hegemony and influence - we believe it necessary to first and quite precisely discern what the Western influence in lexicography is. In doing so, we strive not to downplay — but rather to recognize and uplift-local agency in the structural and discursive legacy of traditional lexicography. Leezenberg advocates for a middle way and concludes to not pursue this question further. This is possible in a mature field. We, however, are making the case for a nascent field where such questions still need to be asked and addressed. As such, an essential element of this conversation involves acknowledging that linguistic violence against Indigenous languages can be, has been, and continues to be perpetrated by traditional forms of dictionary

9. Clifford Abbott, "Lessons from an Oneida Dictionary," Dictionaries: Journal of the Dictionary Society of North America 19 (1998): 124-34; Cablitz, "Documenting Cultural Knowledge"; Sandra Chung and Elizabeth Diaz Rechebei, "Community Engagement in the Revised Chamorro-English Dictionary," Dictionaries: Journal of the Dictionary Society of North America 35 (2014): 308-17; Corris et al., "Dictionaries and Endangered Languages"; Cristinoi and Nemo, "Challenges in Endangered Language Lexicography”; Dyck and Kumar, "Grammar-Driven Bilingual Digital Dictionary for Cayuga”; William Frawley, Kenneth C. Hill, and Pamela Munro, Making Dictionaries: Preserving Indigenous Languages of the Americas (Berkeley: University of California Press, 2002); Sharon Hargus, "Design Issues in Athabaskan Dictionaries," Northwest Journal of Linguistics 6, no. 2 (2012): 1-14; Kenneth C. Hill, "Technical Report on the Hopi Dictionary Project," Dictionaries: Journal of the Dictionary Society of North America 17 (1996): 156-79; Kroskrity, "Designing a Dictionary"; Michael Maxwell and William Poser, "Morphological Interfaces to Dictionaries," ElectricDict'04, in Proceedings of the Workshop on Enhancing and Using Electronic Dictionaries, ed. Michael Zock and Patrick Saint Dizier (Stroudsburg, PA: Association for Computational Linguistics, 2004), 65-68; Pamela Munro, "Making a Zapotec Dictionary," Dictionaries: Journal of the Dictionary Society of North America 17 (1996): 131-55; Sarah Ogilvie, "Linguistics, Lexicography, and the Revitalization of Endangered Languages," International Journal of Lexicography 24, no. 4 (2011): 389-404; William J. Poser, "Making Athabaskan Dictionaries Usable," in Proceedings of the 2002 Athabaskan Language Conference, Fairbanks, Alaska, June 16-18, 2002, ed. Gary Holton (Fairbanks: Alaska Native Language Center, 2002), 136-47; Rottet, "Neology, Competing Authenticities, and the Lexicography of Regional Languages"; Sikorsky, "Community-Based Lexicography."

10. Michiel Leezenberg, "Internalized Orientalism or World Philology? The Case of Modern Turkish Studies," in this issue. 
making, which not only shape dictionaries of underresourced languages at a structural level but also impact the relationships among creators, speakers, and users.

\section{THE AUTHORITY OF WORDS: PRESCRIPTION TO DESCRIPTION}

We start this section by exploring the dictionary's relationship to authority and power and its role in the perceived advancement of nation-states across the world and throughout history. In his definitive Imagined Communities: Reflections on the Origin and Spread of Nationalism, Benedict Anderson identified the "lexicographic revolution in Europe" as having both created and then spread the "conviction that languages ... were, so to speak, the personal property of quite specific groups - their daily speakers and readers - and moreover that these groups, imagined as communities, were entitled to their autonomous place in a fraternity of equals." ${ }^{\prime 1}$ Does having a written dictionary grant a body of people the power and authority to be a distinct community, perhaps even a nation-state, or is having a written dictionary a result of having authority and exercising power in a way that can define and exclude? Or to borrow Leezenberg's phrasing, is the existence of a dictionary a manifestation of "the creation of state power," or is it a "precondition" for exercising state power? ${ }^{12}$ Given that many early dictionaries of North American languages were the direct product of colonizing efforts, forced assimilation, and attempted religious conversion intentionally executed by settler colonial nation-states over sovereign Indigenous peoples, it seems prudent to ask this question.

By introducing "criticality in lexicography," we also need to take stock of, and theorize, the ways in which the role and value of a dictionary extends far beyond the simple collection and collation of words for members of historically marginalized speech communities. We acknowledge that we are situated in a long lineage of scholars to note this: 150 years ago, Trench reached a similar conclusion when he noted that "a Dictionary is an historical monument, the history of a nation contemplated from one point of view, and the wrong ways into which a language has wandered, or attempted to wander may be just as instructive as the right ones in which it has travelled: as much may be learned, or nearly as much, from its failures as its successes, from its follies as from its wisdom." ${ }^{13}$ Putting such imperial and hegemonic images to one side, we may simply note that dictionary practitioners in 1857 understood full well the influence

11. Benedict Anderson, Imagined Communities: Reflections on the Origin and Spread of Nationalism (London: Verso Books, 2006, first published 1983), 86.

12. Leezenberg, "Internalized Orientalism or World Philology?"

13. Trench, On Some Deficiencies in Our English Dictionaries, 6. 
that their lexicographic practices and decisions would have, not only on how a language became inscribed and registered in the written historical record, but also in encoding social assumptions and attitudes. Pulling back further still, we might observe that over 2,000 years ago, Socrates theorized that the seductively authoritative nature of the written word could entice as well as mislead: "A more subtle concern for Socrates is that written words can be mistaken for reality; their seeming impermeability masks their essentially illusory nature. Because they "seem . . . as though they were intelligent" and, therefore, closer to the reality of a thing, words can delude people, Socrates feared, into a superficial, false sense that they understand something when they have only just begun to understand it." ${ }^{14}$ What better way of exploring the perceived impermeability of the written word than by examining and addressing the very documents that define and control its use and dissemination? A growing body of recent literature engages with such questions, exploring how dictionaries offer a lens into a society, a community, and a culture at a certain point in time from a certain perspective - a lexical snapshot of the linguistic values, beliefs, and ideologies of the moment. ${ }^{15}$ Through such work, it has become increasingly apparent that dictionaries are neither passive nor inert documents and are anything but neutral.

As a case in point, coauthor Mark Turin was asked by his research partners in $\mathrm{Ne}$ pal to assume authorship, and thereby responsibility, for the first-ever dictionary of the Thangmi (also known as Thami) language. As the first ever lexical compilation of this underdocumented Tibeto-Burman language, the publication was expected to be politically inflammatory and polarizing. Thangmi community researchers, with whom $\mathrm{Tu}$ rin had collaborated for years in the preparation of this publication, were at once eager to see it in print and yet concerned about the potential of negative fallout and sociopolitical repercussions. They rightly anticipated that following the publication, there would be much public discussion within the community about which (head)words had been included, which orthography had been used, and which of the various regional variations and dialects had received most attention. The compromise was to ask Turin, the outside linguist, to assume primary authorship and propose that Bir Bahadur Thami, his longtime research collaborator, be listed on the cover under the intentionally vague byline "with." This subdominant billing would both acknowledge Bir Bahadur's central involvement and investment in the project but also insulate him

14. Marianne Wolf, Proust and the Squid: The Story and Science of the Reading Brain (Thriplow: Icon Books, 2008), 74.

15. Kroskrity, "Designing a Dictionary"; Sarah Shulist, Lavanya Murali Proctor, and Michael P. Oman-Reagan, "The Power of the Dictionary," Sapiens, December 8, 2016, https://www.sapiens.org /language/dictionary-prejudice/. 
somewhat from the fallout. ${ }^{16}$ This case offers a simple illustration of the ways in which dictionaries are powerful political texts that effect change, embed values, create ideologies, and reinscribe power structures. And as we know, dictionaries have an agency and impact that does not always sit comfortably with their compilers nor with their eventual users.

In 2016, Sarah Shulist, Lavanya Murali Proctor, and Michael Oman-Reagan exposed the gendered nature of example sentences in some of the most widely used Englishlanguage dictionaries. Oman-Reagan demonstrated that example sentences for words with possible negative connotations, such as shrill, nagging, rabid, promiscuous, and grating, made use of female agents (e.g., "a nagging wife"), while male actors were used to illustrate definitions of words of esteem and accomplishment, such as doctor, researcher, and the like. A storm of discussion using the hashtag \#OxfordSexism erupted on Twitter, where the debate was not restricted to the choice of words in these problematic entries but centered on "much deeper issues of sexism in language and linguistic authority - about how dictionaries are perceived, and about the nature and creation of linguistic meanings and truths." ${ }^{17}$ From insightful and indeed necessary discussions such as these, we are reminded of how the presentation of such putatively "illustrative" definitions help to perpetuate socially constructed and harmful gender stereotypes that institutionalize sexism through the authority of the dictionary.

As the above examples illustrate, even though we are not usually taught to question the power and influence of dictionaries — or the social values embedded within themwe would do well to challenge dictionaries to model the society in which we aspire to live, rather than reify entrenched privileges so that each generation learns them anew. As Shulist, Proctor, and Oman-Reagan caution, "every time we turn to a dictionary to illustrate a point or to prove that we understand the "true" and "accurate" meaning of a word or phrase, we reinforce the dictionary's power as a purveyor of truth. It becomes easy to argue that women's voices really are shrill or grating, and that feminists really are rabid about their beliefs_- because it says so in the dictionary." ${ }^{18}$

Such discussions about the authority of a dictionary, and the OED in particular, are not new. Charlotte Brewer discusses how "omission is a covert form of linguistic prescriptivism" citing that the OED's refusal to include the sexual meaning of the word lesbian in its 1933 supplement was in fact "motivated by factors other than legality." 19

16. Mark Turin with Bir Bahadur Thami, Nepali-Thami-English Dictionary. (Kathmandu: Martin Chautari, 2004).

17. Shulist et al., "Power of the Dictionary."

18. Ibid.

19. Charlotte Brewer, "Prescriptivism and Descriptivism in the First, Second and Third Editions of the OED," English Today 26, no. 2 (2010): 27. 
However, in other instances the $O E D$ has taken a "descriptive attitude to racist and other sorts of offensive vocabulary," and "both publishers and lexicographers had consistently taken the view that, since $O E D$ was a descriptive dictionary, it could not suppress or censor historical evidence and it was bound to record 'the facts of the language." " 20 The debates between descriptivism and prescriptivism in lexicography are as old as the field itself, ${ }^{21}$ but we see them as becoming particularly heated and heightened for dictionaries of underresourced languages. This ubiquitous challenge of balancing descriptivism and prescriptivism in dictionary projects of Indigenous languages can take many forms, a common issue being how to represent (describe) different dialects or variations of a language in a dictionary without identifying a standard form (prescribe).

The Inuktut Lexicon Atlas is just one example of an ongoing project that is identifying creative ways to recognize dialect and variation. The term Inuktut is used because it encompasses all the dialects that are spoken in the Inuit regions of Canada, known as Inuit Nunangat. This dictionary project was created to "help protect and strengthen the vitality of Inuktut dialects in Canada," and as such this online atlas is "a place where all dialects are equal, whether there are thousands of speakers or only a few, or whether they are spoken in communities large or small." ${ }^{22}$ The atlas offers different ways to view and access words in all dialects represented, including word lists, dialect charts, and interactive community and dialect maps. This interactive, online, and multimedia format ensures that no one dialect is prioritized or presented as being the prescribed "standard."

Scholars have argued that Western humanism has imposed systems of perceived or imagined hierarchies in both theory and practice. With respect to languages that have more recent written traditions, we note that Western humanism has imposed a series of imagined hierarchies - a kind of lexicographic linearity — by which a language must be described before it can be prescribed. All early dictionaries of Indigenous and underresourced languages have followed this model, and in this contribution, we propose a rupturing — or at the very last, an inversion — of this conventional practice, by first identifying and then challenging this anticipated linearity. Dictionaries need not be prescriptive, and particularly in the case of Indigenous and underresourced languages, prescription (if needed at all) and description can be undertaken in tandem, and must be undertaken with care. In drawing attention to this debate, we do not seek to highlight one dictionary's specific practice over another or to single out the $O E D$ for some special

20. Ibid., 26-27.

21. Brewer, "Prescriptivism and Descriptivism."

22. Inuktut Lexicon Atlas, https://inuktutlexicon.gcrc.carleton.ca/index.html?module=module .inuktutlexicon_about. 
opprobrium. Rather, we provide these examples in order to illustrate that, while dictionaries can often unwittingly perpetuate inequities, they also have the power to subvert them.

As discussions about the societal impact of sexist representations in majority language dictionaries circulate on media outlets, we raise the related question of the role that dictionary projects can play in Indigenous communities' assertions of authority, access, sovereignty, and self-determination. We situate our contribution in the growing body of work that engages with issues of ownership, control, access, and possession, ${ }^{23}$ discussions of which have recently been played out in the pages of various journals. ${ }^{24}$

The structure of the remainder of this contribution is as follows. First, we situate our understanding of criticality in lexicography in the wider context of critical genre theory and critical Indigenous studies. Second, we address why a new orientation of lexicography that emerges out of - and yet moves on from - conventional lexicographic practice is necessary for those working to create dictionaries of Indigenous and underresourced languages. We conclude this contribution by proposing three features and four practices that we believe are specific to underresourced and Indigenous languages and that we are currently developing into a theoretical and practical framework for accountability, transformation, and engagement in the construction of dictionaries.

\section{CLARIFYING "CRITICALITY": IT'S NOT ABOUT COMPLAINING}

Before turning to the indicators, we must clarify what we mean by introducing criticality in lexicography. How better to initiate that conversation than by exploring how dictionaries themselves define and describe the root of the term. The Merriam-Webster Dictionary and the Oxford English Dictionary define "critical" as

(1) a level of criticism; "Given to judging; esp. given to adverse or unfavourable criticism; fault-finding, censorious" 25

23. See "The First Nations Principles of OCAP"," First Nations Information Governance Centre, Akwesasne, http://fnigc.ca/ocapr.html.

24. Abbott, "Lessons from an Oneida Dictionary"; Yasmin Baksh-Comeau and Lise Winer, "Grasping the Nettle: Handling Flora Entries in Dictionaries," Dictionaries: Journal of the Dictionary Society of North America 37 (2016): 36-59; Chung and Rechebei, "Community Engagement in the Revised Chamorro-English Dictionary"; Dyck and Kumar, "Grammar-Driven Bilingual Digital Dictionary for Cayuga"; Orin Hargraves, "Trademarks and the Lexicographer in the Digital Age," Dictionaries: Journal of the Dictionary Society of North America 36 (2015): 88-99; Hill, "Technical Report on the Hopi Dictionary Project"; David Jost, "Thirty-Four Years of Dictionaries," Dictionaries: Journal of the Dictionary Society of North America 35 (2014): 36-92; Munro, "Making a Zapotec Dictionary."

25. Oxford English Dictionary Online, s.v. "critical." 
(2) some type of crucial turning point; "of, relating to, or being a turning point or specially important juncture"26

(3) a mode of literary/social science critique; "(a) critical theory, a dialectical critique of society (esp. of the theoretical bases of its organization) associated with the leaders of the Institute for Social Research at Frankfurt (the Frankfurt School). ${ }^{27}$

There is an agreeable irony in resorting to authoritative dictionaries of the English language to ground-truth our project. The fact that the word critical has a range of different senses, all of which appear under the same lemma, illustrates not only the importance of the dictionary as a resource but also exemplifies the centuries of lexicographic tradition that have informed the construction of some of the most relied upon dictionaries in the English-speaking world.

The definitions drawn from these two dictionaries show that critical has many meanings, and we ask the reader to note that we are not being critical of the field of lexicography or of lexicographic practices in the first listed sense of the word. We do not eschew the traditions of lexicography; in fact, we recognize and uplift the generations of skilled lexicographers who have built the disciplinary infrastructure that has led to the creation of dictionaries across the world. Instead, we ask fellow language workers engaged with Indigenous and minority languages to think critically about their process, about the ways they approach and undertake their lexicographic projects and to reflect on what makes the creation of a dictionary of Kaska, Ojibwe, or Navajo different from the creation of a dictionary of French, English, or German. Likewise, new collaborative and community-driven dictionaries often address the ways they build upon dictionary projects undertaken in earlier, more conventional lexicographic times. The ongoing, Tlingit-led, "living" Tlingit Online Dictionary acknowledges the ways in which a long lineage of Tlingit dictionaries has fundamentally informed, and been incorporated into, this online dictionary project. The dictionary pays homage to these earlier projects by thanking and acknowledging compilers, linguists, speakers, and community members alike. ${ }^{28}$

As a field, lexicography developed to accommodate the needs of majority European languages, many of which are structurally similar to one another. ${ }^{29}$ Through

26. Merriam-Webster Online Dictionary, s.v. "critical."

27. Oxford English Dictionary Online, s.v. "critical."

28. X’unei Lance Twitchell, ed., Tlingit Online Dictionary (Juneau: Goldbelt Heritage Foundation), http://tlingitlanguage.com/resources/dictionary-2/.

29. B. T. Sue Atkins and Michael Rundell, The Oxford Guide to Practical Lexicography (New York: Oxford University Press, 2008). 
colonization and imperialism, a number of European languages - whether English, French, Spanish, Portuguese, or Dutch - are now the primary or even official language spoken in countries far beyond the reaches of Western Europe. The majority of people undertaking dictionary projects in Native North America speak, read, and write English, French, or Spanish fluently or as their first language, and most of their early exposure to dictionaries as users or practitioners of lexicography will have been with dictionaries of European languages. However, given that the grammatical structures of Indigenous languages from North America are quite different than those of European languages, language workers - whether community stakeholders or outside researchers - need to address the difficulties that such structural differences pose in the creation of their dictionaries, ${ }^{30}$ and adapt their work accordingly. To give just one example, verbs function very differently in Athabaskan languages than they do in, say, English or Spanish, and a perennial question in compiling dictionaries of Athabaskan languages is how to accurately represent verb forms in a dictionary and to do so in a way that allows users to locate the verb they're looking for.

This realignment is not a dismantling of lexicography or its scientific and analytical practices but rather an enrichment that seeks to develop new practices for creating dictionaries of, for, and in Indigenous languages that accommodate and reflect the structures of the languages themselves and better address the strategic, political, and intellectual goals of the language community. The "practices" involved in such a recalibration are not limited to lexicographical customs or habits but extend more broadly to encompass many of the other professional and social actions in which we engage when creating dictionaries. We think in particular of what the First Nations in BC Knowledge Network has termed "inspired practices" rather than more conventional understandings of "best practices." ${ }^{11}$ Similarly, "wise practices," originally developed in health research with First Nations, integrate traditional "wisdom" with mainstream practice to provide a more comprehensive and situational model than that which is conveyed by conventional "best practices." ${ }^{\text {" }} 2$ We highlight this difference because "best practices" are not always feasible, sustainable, or equitable, while the term "inspired practice" or "wise practice" invites language workers to consider the complex social,

30. Poser, "Making Athabaskan Dictionaries Usable"; Maxwell and Poser, "Morphological Interfaces to Dictionaries."

31. Jennifer Carpenter et al., "Digital Access for Language and Culture in First Nation Communities” (Knowledge Synthesis Report, Social Sciences and Humanities Research Council of Canada, Vancouver, 2016), https://heiltsuk.sites.olt.ubc.ca/files/2016/11/Digital_Language_Access_ExecSummary _2016.pdf.

32. Herbert Nabigon and Annie Wenger-Nabigon, "'Wise Practices': Integrating Traditional Teachings with Mainstream Treatment Approaches," Native Social Work Journal 8 (2012): 43-55. 
cultural, and historical contexts in which their dictionary projects are situated and encourages the recognition of the plurality and inclusion of diverse approaches.

\section{EMBRACING CRITICAL THEORY AND ENGAGING WITH CRITICAL INDIGENOUS STUDIES}

We draw on a different sense of critical to explore how a reorientation toward a critically informed lexicography can be assisted by the foundational historical work of critical (social) theory and the emerging field of critical Indigenous studies. In what came to be known as the Frankfurt School, critical theory was initiated by a group at the Institute of Social Research in Frankfurt in the 1930s. ${ }^{33}$ While a broad term, in general, critical theory "tends to dig deeper to identify problems as well as limitations inherent in human communication that often lead to injustices and inequities in social structures." ${ }^{34}$ Critical theory emerged as academics and philosophers identified the need to (1) critique conditions that were understood or prescribed and (2) seek emancipation from these conditions ${ }^{35}$ Critical theory is not outward facing but rather calls its practitioners to be self-reflexive and critical of their own epistemologies, ideologies, methods, and modes of overall inquiry. Although critical theory has been taken up by practitioners of diverse disciplines, it is best known as being used in literary criticism and for social and political critique, ${ }^{36}$ and it is as an extension of the latter that we use it here.

More recently, critical theory has provided the basis for a growing understanding and acknowledgment within the academy that criticality is vital to intellectual inquiry because it informs scholarship and can generate positive effects and social change. Vijay Bhatia proposes that critical genre analysis (derived from critical theory) has implications in the professional realm both inside and outside of academia, because critical theory can be used to (1) question "the motives of such social communities, institutions and organizations which underpin injustices and power imbalances" and (2) illustrate how such questioning can "remedy social improprieties and attempt to restore power equality and justice in society to make it a better place." ${ }^{37} \mathrm{We}$ are by

33. Diana Boros, "Critical Theory and the Frankfurt School," in Oxford Bibliographies (Oxford: Oxford University Press, 2017), https://doi.org/10.1093/OBO/9780199756223-0161; Neil McLaughlin, "Origin Myths in the Social Sciences: Fromm, the Frankfurt School and the Emergence of Critical Theory," Canadian Journal of Sociology/Cahiers Canadiens de Sociologie 24, no. 1 (1999): 109-39; James Swindal, "Frankfurt School and Critical Social Theory," in Encyclopedia of Philosophy and the Social Sciences, ed. Byron Kaldis (Thousand Oaks, CA: SAGE, 2013), 368-71.

34. Vijay K. Bhatia, “Critical Genre Analysis: Theoretical Preliminaries," Hermes_Journal of Language and Communication in Business 54 (2015): 12.

35. Ibid.; Boros, "Critical Theory."

36. Boros, "Critical Theory."

37. Bhatia, "Critical Genre Analysis," 11. 
no means the first to identify the utility of critical theory in regards to dictionaries. Aligning very much with our position in this contribution, Wenge Chen proposes a critical discourse approach for examining dictionaries of majority languages, arguing that "dictionaries, both as representation of languages and of society and the world, are carriers of ideologies" and as such "lexicographers and their products are part of the ideological reproduction system." ${ }^{38}$ Although our argument takes up the creation of dictionaries of nondominant languages, Chen's work demonstrates the ways that critical theory can also provide a basis for examining and (de)constructing dictionaries of dominant languages.

The emerging field of critical Indigenous studies calls on researchers working with Indigenous communities and Indigenous issues to be both critical of the embedded colonial power structures, histories, and epistemologies in their own research and to reflect on the ways in which they are, or are not, in opposition to Indigenous ways of being and knowing. ${ }^{39}$ Daniel Heath Justice succinctly outlines this approach:

A critical scholarship is meant to help us understand the social systems, historical processes, and ideologies that shape our individual and group experiences, and helps us understand how we got to this historical moment and, just maybe, where we're going. "Critical," then, isn't about negativity or simply challenging ideas in a reactive way, but to insist on the relationship between our intellectual practice and our everyday lives. It's an unwillingness to accept claims based on arbitrary or coercive authority or clichéd received wisdom, but to use all the tools at our disposal to expand possibilities for ethical, thoughtful inquiry. It is a commitment to confronting oppressive and limiting social structures while also imagining possibilities for better ways of co-existing and flourishing in the world. In so doing, however, it necessarily requires us to rigorously question our own perspectives, ways of thinking, and areas of study in pursuit of better, more accountable, and more ethically engaged ways of thinking and doing in the world. $^{40}$

When understood and mobilized in this way, criticality empowers the researcher and the individual to challenge entrenched claims and assumptions about society-as well as about the work in which they are engaged - that are based on hegemonic and

38. Wenge Chen, “Towards a Discourse Approach to Critical Lexicography," International Journal of Lexicography 32, no. 3 (2019): 371.

39. Chris Andersen, "Critical Indigenous Studies: From Difference to Density," Cultural Studies Review 15, no. 2 (2009): 80-100.

40. Daniel Heath Justice, "What Is the Critical in Critical Indigenous Studies?" The Raven 5 (2017): 34. 
institutionally legitimated models of colonial authority, what Walter D. Mignolo has called "the closed circuit of the rhetoric of modernity" and the "collateral damages which indeed are the actual consequences of the logic of coloniality," ${ }^{11}$ and then identify ways to overcome these structures. In such a rendering, the role of the critical thinker is not so much to criticize the field they are in but rather to become critically aware of the existing disciplinary and social structures in which they operate and to be more mindful of how they approach and undertake their work.

\section{CRITICAL INQUIRY AND DECOLONIAL APPROACHES TO LANGUAGE "REVITALIZATION"}

A growing group of scholars are recommending that we draw on critical theory when working with Indigenous languages and their speakers. Haley De Korne and Wesley Y. Leonard contend that "explicit attention to power - what has been termed a critical turn in other social science fields such as education (Gottesman 2010) and applied linguistics (Pennycook 2001) - is needed in responses to language endangerment in order to develop effective approaches to addressing the inequalities perpetuated through and in relation to language practices." ${ }^{\$ 2}$ Similarly, Nathan John Albury notes that the political discourses and language policies implicit in language revitalization are entrenched in colonial suppression and imperialism in ways that necessarily compel language researchers and activists to draw upon critical theory when interrogating them. ${ }^{43}$

We propose that introducing critical theory into language revitalization projects, and into dictionary projects specifically, goes hand in hand with the acknowledgment and inclusion of decolonized practices, views, and methods. Leonard, a Miami community member and linguist, argues that "many Indigenous language research initiatives are intertwined with community efforts toward decolonisation, a process which entails identifying and resisting the imposition of Western values and knowledge systems that contribute to the subjugation of Indigenous peoples." ${ }^{44}$ As such, an initial step in any collaborative language project involves critically examining the various

41. Walter D. Mignolo, “Who Speaks for the 'Human' in Human Rights?” Hispanic Issues On Line 5, no. 1 (2009): 19.

42. Haley De Korne and Wesley Y. Leonard, "Reclaiming Languages: Contesting and Decolonising 'Language Endangerment' from the Ground Up," Documentation and Description 14 (2017): 6, citing Isaac Gottesman, "Sitting in the Waiting Room: Paulo Freire and the Critical Turn in the Field of Education," Educational Studies 46, no. 4 (2010): 376-99; and Alastair Pennycook, Critical Applied Linguistics: A Critical Introduction (Mahwah, NJ: Lawrence Erlbaum Associates, 2001).

43. Nathan John Albury, "Objectives at the Crossroads: Critical Theory and Self-Determination in Indigenous Language Revitalization," Critical Inquiry in Language Studies 12, no. 4 (2015): 256-82.

44. Wesley Y. Leonard, "Producing Language Reclamation by Decolonizing 'Language.'” Language Documentation and Description 14 (2017): 16. 
methods that project members plan to employ as well as the underlying epistemologies on which such methods are grounded. To offer an example, Leezenberg observes the extent to which modern Turkish language grammarians reproduce the categories and ideological preconceptions of modern Western philology in the grammars that they compile. ${ }^{45}$ If this is indeed the case, it either (1) affirms that the Western philological method is right for every grammar; (2) illustrates that grammarians haven't yet created appropriate localized methodologies; or (3) some combination of both. The first dictionaries of Indigenous languages were often compiled by non-native, outside linguists, who harnessed methods developed for languages from Western Europe and applied them to the lexical inventories of languages from North America. These early scholars inevitably reproduced the ideological and epistemological preconceptions baked into a Western-informed lexicography of what language is and how it should be categorized. As such, we view the implementation of methods based exclusively in Western ideologies and epistemologies as signaling that scholars have not yet created appropriately localized and specific methodologies for working with Indigenous languages.

Many users of early dictionaries of North American languages continue to grapple with how to best interpret and utilize these rich resources for contemporary linguistic understanding, on account of the disconnect between the extractive methods used to create and compile these collections and the goals of the living language community. There is no simple path for working through such philosophical and methodological challenges. Historical inequities in authorship and authority combined with pernicious linguistic misrepresentations that enter the scholarly and popular record perpetuate injustice and reinscribe subjugation. ${ }^{46}$ As key components in many Indigenous language research initiatives, dictionaries are inescapably intertwined with and implicated in community efforts toward intellectual and practical decolonization and can therefore contribute to movements for Indigenous sovereignty. One example of such a process is the Algonquian Linguistic Atlas, which made use of dictionary projects of languages in the Algonquian language family to design and build an online, interactive map that identifies and situates ancestral place names of Algonquian peoples' traditional territories in what is now Canada and the United States. ${ }^{47}$

Just as we propose that an introduction of criticality in lexicography does not entail a rejection of lexicography or its professional practices but is rather a reorientation in

45. Leezenberg, "Internalized Orientalism or World Philology?"

46. See Mignolo, "Who Speaks for Human Rights?"

47. School of Linguistics and Applied Language Studies, Algonquian Linguistic Atlas (Ottawa: School of Linguistics and Applied Language Studies, Carleton University, n.d.), https://www.atlas -ling.ca/. 
the context of ethically engaged language work, Linda Tuhiwai Smith proposes that decolonization "does not mean and has not meant a total rejection of all theory or research or Western knowledge. Rather, it is about centering our concerns and world views then coming to know and understand theory and research from our own perspectives and for our own purposes." ${ }^{38}$ In her contribution to this volume, Daniela Merolla discusses how - contrary to popular assumptions - Kabyle speakers and researchers actively chose to generate and determine their own discussions through a conscious mobilization of colonial knowledge. This offers a persuasive example of how decolonizing practices can productively involve the use, adaptation, and implementation of practices that were developed within, and by, colonial contexts.

However, Eve Tuck and K. Wayne Yang caution us to remember that decolonization is not a metaphor for reconciliation but rather a framework that often offers perspectives that are at once unsettling and uncomplimentary to our internalized approaches to research that remain grounded in settler colonial ways of knowing and being. Or put another way, "decolonization is not an 'and.' It is an elsewhere." ${ }^{\prime 49}$ Seen this way, we suggest that language workers must (1) become more aware of how their dictionary projects factor into wider decolonial efforts and activities, (2) think through how and when to incorporate decolonizing methodologies, (3) ask themselves how and why they are using these methods, and (4) reflect on the ways in which any methods they employ embed and represent Indigenous or Western values and knowledge systems. ${ }^{50}$ One way of working toward a "decolonial humanities" is to learn from frameworks for research and engagement that have been developed by, and in collaboration with, Indigenous researchers, such as the Indigenous-focused “Four R's" framework of

48. Linda Tuhiwai Smith, Decolonizing Methodologies: Research and Indigenous Peoples (London: Zed Books, 1999), 41.

49. Eve Tuck and K. Wayne Yang, "Decolonization Is Not a Metaphor," Decolonization: Indigeneity, Education \& Society 1, no. 1 (2012): 36.

50. For further discussion, see De Korne and Leonard, "Reclaiming Languages"; Nelson Flores, "Silencing the Subaltern: Nation-State/Colonial Governmentality and Bilingual Education in the United States," Critical Inquiry in Language Studies 10, no. 4 (2013): 263-87; Mary Hermes, "Indigenous Language Revitalization and Documentation in the United States: Collaboration Despite Colonialism," Language and Linguistics Compass 6, no. 3 (2012): 131-42; Mary Hermes and Mel M. Engman, "Resounding the Clarion Call: Indigenous Language Learners and Documentation," Language Documentation and Description 14 (2017): 59-87; Antje Hornscheidt, "A Concrete Research Agenda for Critical Lexicographic Research within Critical Discourse Studies: An Investigation into Racism/Colonialism in Monolingual Danish, German, and Swedish Dictionaries," Critical Discourse Studies 5, no. 2 (2008): 107-32; Margaret Kovach, Indigenous Methodologies: Characteristics, Conversations and Contexts (Toronto: University of Toronto Press, 2009); Leonard, "Producing Language Reclamation"; Smith, Decolonizing Methodologies. 
"Respect, Reciprocity, Responsibility, and Relevance" outlined by Verna J. Kirkness and Ray Barnhardt. ${ }^{51}$

In working through how to deliver such change, De Korne and Leonard propose that "in some contexts a critical turn may constitute a paradigm shift; in others it may be an amplification or legitimation of concerns that are already present." ${ }^{\prime 2}$ In this contribution, we contend that criticality in lexicography embraces both these possibilities: it is a form of paradigm shift (or "reorientation") but is one that augments existing concerns that are present in dictionary projects with endangered, Indigenous, historically marginalized, or underresourced languages and speaks to existing apprehensions articulated by Indigenous scholars and communities more widely.

\section{CRITICALITY IN LEXICOGRAPHY: A BETTER LANGUAGE FOR TALKING ABOUT LANGUAGE}

As we begin to develop specific practices for introducing criticality in lexicography, it behooves us to reflect on the words that we have chosen to describe this work, and note in particular a growing resistance to the term "language revitalization" among Indigenous scholars. Language researchers are problematizing the phrase "language revitalization" as it makes implicit colonial assumptions about the imagined "vitality" (or lack thereof) of Indigenous languages, proposing instead that alternative terms be adopted that more accurately reflect community understandings and goals..$^{53}$ Leonard proposes a reorientation to the term "language reclamation" that "recognizes that in certain worldviews, what in Western science would be considered social factors that are merely associated with language might instead be part of what someone understands language to 'be.'”54 Just as Leonard encourages us to think through ways that language embodies wider meanings and significance than we have traditionally been taught to recognize, we invite readers to explore how lexicography may do the same.

Having established the intellectual case for such an approach through this brief manifesto, we conclude by outlining some practical next steps that we seek to introduce into lexicography. We consider there to be at least three features specific to dictionary

51. Mignolo, "Who Speaks for Human Rights?"; Verna J. Kirkness and Ray Barnhardt, "First Nations and Higher Education: The Four R's - Respect, Relevance, Reciprocity, Responsibility," Journal of American Indian Education 30, no. 3 (1991): 1-15.

52. De Korne and Leonard, "Reclaiming Languages," 7.

53. Jenny L. Davis, "Resisting Rhetorics of Language Endangerment: Reclamation through Indigenous Language Survivance," Language Documentation and Description 14 (2017): 37-58; Leonard, "Producing Language Reclamation"; Aidan Pine and Mark Turin, "Language Revitalization," in Oxford Research Encyclopedia of Linguistics, ed. Mark Aronoff (New York: Oxford University Press, 2017), https://doi.org/10.1093/acrefore/9780199384655.013.8.

54. Leonard, "Producing Language Reclamation," 19-20. 
projects with, for, and in underresourced and Indigenous languages that warrant closer inspection going forward. Such languages may have, on account of colonization and assimilation, (1) reduced lexical inventories, (2) fewer fluent speakers, and (3) unique and complex grammatical structures. We are currently working to develop four initial practices for introducing criticality in lexicography in support of marginalized languages that those of us working with such language communities may wish to attend to, including (1) more ethical and balanced understandings of partnership and collaboration, (2) distinct and more egalitarian models of authorship and authority, (3) greater recognition of the central role that archival recordings and heritage language resources can play in designing a dictionary project, and (4) an appreciation of diverse outputsnot limited to printed dictionaries - that increasingly include mobile apps, online platforms, talking dictionaries, and pedagogical resources produced in, and by, language communities for use in formal and informal education settings.

It is our provisional contention that an acknowledgment of these features and an engagement with these practices might indicate that a dictionary project, and the people undertaking it, are open to a critical self-awareness in terms of how they undertake lexicography and of the lasting impact their project may have for language communities. Conversely, researchers embarking on a dictionary project might care to reflect on these features and practices as they prepare for their forthcoming work. As we continue to further refine these practices, we invite researchers working with endangered, Indigenous, historically marginalized, or underresourced languages to consider the ways in which they might introduce criticality into their lexicography projects and how such approaches may lead to dictionary work that is more balanced, equitable, respectful, and durable.

\section{WORKS CITED}

Abbott, Clifford. 1998. "Lessons from an Oneida Dictionary." Dictionaries: Journal of the Dictionary Society of North America 19:124-34.

Ahmed, Siraj. 2017. Archaeology of Babel: The Colonial Foundation of the Humanities. Stanford, CA: Stanford University Press.

Albury, Nathan John. 2015. "Objectives at the Crossroads: Critical Theory and Self-Determination in Indigenous Language Revitalization.” Critical Inquiry in Language Studies 12 (4): 256-82.

Algonquian Linguistic Atlas. Ottawa: School of Linguistics and Applied Language Studies, Carleton University. https://www.atlas-ling.ca/.

Andersen, Chris. 2009. "Critical Indigenous Studies: From Difference to Density." Cultural Studies Review 15 (2): 80-100.

Anderson, Benedict. (1983) 2006. Imagined Communities: Reflections on the Origin and Spread of $\mathrm{Na}$ tionalism. London: Verso Books.

Atkins, B. T. Sue, and Michael Rundell. 2008. The Oxford Guide to Practical Lexicography. New York: Oxford University Press. 
Baksh-Comeau, Yasmin, and Lise Winer. 2016. "Grasping the Nettle: Handling Flora Entries in Dictionaries." Dictionaries: Journal of the Dictionary Society of North America 37:36-59.

Bhatia, Vijay K. 2015. "Critical Genre Analysis: Theoretical Preliminaries." Hermes-Journal of Language and Communication in Business 54:9-20.

Boros, Diana. 2017. "Critical Theory and the Frankfurt School." In Oxford Bibliographies. Oxford: Oxford University Press. https://doi.org/10.1093/OBO/9780199756223-0161.

Brewer, Charlotte. 2010. "Prescriptivism and Descriptivism in the First, Second and Third Editions of the OED.” English Today 26 (2): 24-33.

Cablitz, Gabriele H. 2011. "Documenting Cultural Knowledge in Dictionaries of Endangered Languages.” International Journal of Lexicography 24 (4): 446-62.

Carpenter, Jennifer, Annie Guerin, Michelle Kaczmarek, Gerry Lawson, Kim Lawson, Lisa P. Nathan, and Mark Turin. 2016. "Digital Access for Language and Culture in First Nation Communities." Knowledge Synthesis Report for Social Sciences and Humanities Research Council of Canada, Vancouver.

Chelliah, Shobhana L., and Willem J. de Reuse. 2011. "Lexicography in Fieldwork." In Handbook of Descriptive Linguistic Fieldwork, edited by Shobhana L. Chelliah and Willem J. de Reuse, 22749. New York: Springer.

Chen, Wenge. 2019. “Towards a Discourse Approach to Critical Lexicography.” International Journal of Lexicography 32 (3): 362-88.

Chung, Sandra, and Elizabeth Diaz Rechebei. 2014. "Community Engagement in the Revised Chamorro-English Dictionary." Dictionaries: Journal of the Dictionary Society of North America 35:308-17.

Corris, Miriam, Christopher Manning, Susan Poetsch, and Jane Simpson. 2002. "Dictionaries and Endangered Languages." In Language Endangerment and Language Maintenance: An Active Approach, edited by David Bradley and Maya Bradley, 329-47. New York: Routledge.

Cristinoi, Antonia, and François Nemo. 2013. "Challenges in Endangered Language Lexicography." In Lexicography and Dictionaries in the Information Age: Selected Papers from the 8th ASIALEX International Conference, edited by Deny A. Kwary, Nur Wulan, and Lilla Musyahda, 126-31. Surabaya: Airlangga University Press. https://halshs.archives-ouvertes.fr/halshs-01345620.

Davis, Jenny L. 2017. "Resisting Rhetorics of Language Endangerment: Reclamation through Indigenous Language Survivance.” Language Documentation and Description 14:37-58.

De Korne, Haley, and Wesley Y. Leonard. 2017. "Reclaiming Languages: Contesting and Decolonising 'Language Endangerment' from the Ground Up." Language Documentation and Description 14:514.

Dyck, Carrie, and Ranjeet Kumar. 2012. “A Grammar-Driven Bilingual Digital Dictionary for Cayuga.” Dictionaries: Journal of the Dictionary Society of North America 33:179-204.

First Nations Information Governance Centre. n.d. "The First Nations Principles of OCAP." First Nations Information Governance Centre, Akwesasne. http://fnigc.ca/ocapr.html.

Flores, Nelson. 2013. "Silencing the Subaltern: Nation-State/Colonial Governmentality and Bilingual Education in the United States." Critical Inquiry in Language Studies 10 (4): 263-87.

Frawley, William, Kenneth C. Hill, and Pamela Munro. 2002. Making Dictionaries: Preserving Indigenous Languages of the Americas. Berkeley: University of California Press.

Gottesman, Isaac. 2010. "Sitting in the Waiting Room: Paulo Freire and the Critical Turn in the Field of Education.” Educational Studies 46 (4): 376-99.

Hargraves, Orin. 2015. "Trademarks and the Lexicographer in the Digital Age." Dictionaries: Journal of the Dictionary Society of North America 36:88-99.

Hargus, Sharon. 2012. "Design Issues in Athabaskan Dictionaries." Northwest Journal of Linguistics 6 (2): 1-14. 
Hermes, Mary. 2012. "Indigenous Language Revitalization and Documentation in the United States: Collaboration Despite Colonialism.” Language and Linguistics Compass 6 (3): 131-42.

Hermes, Mary, and Mel M. Engman. 2017. "Resounding the Clarion Call: Indigenous Language Learners and Documentation.” Language Documentation and Description 14:59-87.

Hill, Kenneth C. 1996. “Technical Report on the Hopi Dictionary Project.” Dictionaries: Journal of the Dictionary Society of North America 17:156-79.

Hornscheidt, Antje. 2008. "A Concrete Research Agenda for Critical Lexicographic Research within Critical Discourse Studies: An Investigation into Racism/Colonialism in Monolingual Danish, German, and Swedish Dictionaries." Critical Discourse Studies 5 (2): 107-32.

Inuktut Lexicon Atlas. n.d. Carleton University, Ottawa; University of Toronto; Department of Culture and Heritage, Government of Nunavut, Iqaluit; Inuit Tapiriit Kanatami, Ottawa; Inuit Uqausinginnik Taiguusiliuqtiit, Iqaluit; Inuvialuit Cultural Resource Centre, Inuvialuit Regional Corporation, Inuvik; Kitikmeot Heritage Society, Cambridge Bay; Torngâsok Cultural Centre, Nunatsiavut Government, Nain. Accessed July 16, 2020. https://inuktutlexicon.gcrc.carleton.ca /index.html?module=module.inuktutlexicon_about.

Jost, David. 2014. “Thirty-Four Years of Dictionaries.” Dictionaries: Journal of the Dictionary Society of North America 35:36-92.

Justice, Daniel Heath. 2017. "What Is the Critical in Critical Indigenous Studies?" The Raven 5:34.

Kirkness, Verna J., and Ray Barnhardt. 1991. "First Nations and Higher Education: The Four R's - Respect, Relevance, Reciprocity, Responsibility.” Journal of American Indian Education 30 (3): 1-15.

Kovach, Margaret. 2009. Indigenous Methodologies: Characteristics, Conversations and Contexts. Toronto: University of Toronto Press.

Kroskrity, Paul V. 2015. "Designing a Dictionary for an Endangered Language Community: Lexicographical Deliberations, Language Ideological Clarifications." Language Documentation and Conservation 9:140-57.

Leonard, Wesley Y. 2017. "Producing Language Reclamation by Decolonizing 'Language.'” Language Documentation and Description 14:15-36.

Maxwell, Michael, and William Poser. 2004. "Morphological Interfaces to Dictionaries." In Proceedings of the Workshop on Enhancing and Using Electronic Dictionaries, edited by Michael Zock and Patrick Saint Dizier, 65-68. Stroudsburg, PA: Association for Computational Linguistics.

McLaughlin, Neil. 1999. "Origin Myths in the Social Sciences: Fromm, the Frankfurt School and the Emergence of Critical Theory.” Canadian Journal of Sociology/Cahiers Canadiens de Sociologie 24 (1): 109-39.

Mignolo, Walter D. 2009. "Who Speaks for the 'Human' in Human Rights?” Hispanic Issues On Line 5 (1): 7-24.

Munro, Pamela. 1996. “Making a Zapotec Dictionary.” Dictionaries: Journal of the Dictionary Society of North America 17:131-55.

Nabigon, Herbert, and Annie Wenger-Nabigon. 2012. “'Wise Practices': Integrating Traditional Teachings with Mainstream Treatment Approaches.” Native Social Work Journal 8:43-55.

Ogilvie, Sarah. 2011. "Linguistics, Lexicography, and the Revitalization of Endangered Languages." International Journal of Lexicography 24 (4): 389-404.

Pennycook, Alastair. 2001. Critical Applied Linguistics: A Critical Introduction. Mahwah, NJ: Lawrence Erlbaum Associates.

Pinderhughes, Charles. 2011. “Toward a New Theory of Internal Colonialism.” Socialism and Democracy 25 (1): 235-56.

Pine, Aidan, and Mark Turin. 2017. "Language Revitalization." In Oxford Research Encyclopedia of Linguistics, edited by Mark Aronoff. New York: Oxford University Press. https://doi.org/10.1093 /acrefore/9780199384655.013.8. 
Plato. 1961. "Phaedrus." In The Collected Dialogues of Plato, Including the Letters, edited by Edith Hamilton and Huntington Cairns, 475-525. New York: Pantheon Books.

Poser, William J. 2002. "Making Athabaskan Dictionaries Usable." In Proceedings of the 2002 Athabaskan Language Conference, Fairbanks, Alaska, June 16-18, 2002, edited by Gary Holton, 136-47. Fairbanks: Alaska Native Language Center.

Rottet, Kevin J. 2014. "Neology, Competing Authenticities, and the Lexicography of Regional Languages: The Case of Breton." Dictionaries of the Dictionary Society of North America 35:208-47.

Sahlins, Marshall. (1976) 2013. Culture and Practical Reason. Chicago: University of Chicago Press.

Shulist, Sarah, Lavanya Murali Proctor, and Michael P. Oman-Reagan. 2016. "The Power of the Dictionary.” Sapiens, December 8. https://www.sapiens.org/language/dictionary-prejudice/.

Sikorsky, Kathy R. 2002. "Community-Based Lexicography." In Proceedings of the 2002 Athabaskan Language Conference, Fairbanks, Alaska, June 16-18, 2002, edited by Gary Holton, 173-81. Fairbanks: Alaska Native Language Center.

Smith, Linda Tuhiwai. 1999. Decolonizing Methodologies: Research and Indigenous Peoples. London: Zed Books.

Swindal, James. 2013. "Frankfurt School and Critical Social Theory." In Encyclopedia of Philosophy and the Social Sciences, edited by Byron Kaldis, 368-71. Thousand Oaks, CA: SAGE.

Trench, Richard Chenevix. 1857. On Some Deficiencies in Our English Dictionaries: Being the Substance of Two Papers Read before the Philological Society Nov. 5, and Nov. 19, 1857. London: John W. Parker \& Son.

Tuck, Eve, and K. Wayne Yang. 2012. "Decolonization Is Not a Metaphor." Decolonization: Indigeneity, Education \& Society 1 (1): 1-40.

Turin, Mark, with Bir Bahadur Thami. 2004. Nepali-Thami-English Dictionary. Kathmandu: Martin Chautari.

Twitchell, X'unei Lance, ed. 2020. Tlingit Online Dictionary. Juneau, AK: Goldbelt Heritage Foundation. http://tlingitlanguage.com/resources/dictionary-2/.

Wolf, Maryanne. 2008. Proust and the Squid: The Story and Science of the Reading Brain. Thriplow: Icon Books.

Zgusta, Ladislav. 1971. Manual of Lexicography. Edited by Vera Cerny. Prague: Academia Publishing House of the Czechoslovak Academy of Sciences. 